\title{
Induction of apoptosis and necrosis by zinc in human thyroid cancer cell lines
}

\author{
M litaka, S Kakinuma, S Fujimaki, I Oosuga, T Fujita ${ }^{1}$, \\ K Yamanaka, S Wada and S Katayama
}

Department of Internal Medicine 4, Saitama Medical School, 38 Morohongo, Moroyama, Iruma-gun, Saitama 350-0495, Japan
${ }^{1}$ Department of Tumor Cell Biology, The Tokyo Metropolitan Institute of Medical Science, 3-18-22 Honkomagome, Bunkyo-ku, Tokyo 113-0021, Japan
(Requests for offprints should be addressed to M litaka; Email: miitaka@saitama-med.ac.jp)

\begin{abstract}
Zinc at concentrations of $150 \mu \mathrm{M}$ or higher induced necrosis as well as apoptosis in thyroid cancer cell lines. Necrosis was induced by zinc in a dose-dependent manner, whereas apoptosis did not increase at higher concentrations of zinc. The expression of the antiapoptotic protein phosphorylated Bad was markedly increased, whereas the expression of the proapoptotic proteins $\mathrm{Bax}$ and $\mathrm{Bad}$ decreased following $\mathrm{Zn}^{2+}$ exposure. $\mathrm{Zn}^{2+}$ induced rapid degradation of $\mathrm{I} \kappa \mathrm{B}$, and an increase in the binding of
\end{abstract}

nuclear transcription factor- $\kappa \mathrm{B}(\mathrm{NF}-\kappa \mathrm{B})$. These observations indicate that antiapoptotic pathways were activated in thyroid cancer cells following exposure to $\mathrm{Zn}^{2+}$. This may be a self-defence mechanism against apoptosis and may underlie the general resistance of thyroid cancer cells to apoptotic stimuli. Zinc may be a potential cytotoxic agent for the treatment of thyroid cancer.

Journal of Endocrinology (2001) 169, 417-424

\section{Introduction}

Zinc is an essential component of a wide variety of metalloenzymes, transcription factors and other proteins. A deficiency in zinc affects various organs including the nervous system, gonadal tissue, skin and the intestine. Ingestion or administration of excessive amounts of zinc compounds, on the other hand, does not seem to result in any adverse long-term effects (Vallee \& Falchuk 1993).

Most physiologically relevant cell death in the body occurs by an active process of self-destruction known as programmed cell death or apoptosis. Apoptosis can be initiated by a number of external signals including glucocorticoids, irradiation, cytokines, or withdrawal of growth factors (Raff 1992, Williams \& Smith 1993). Several studies have indicated that zinc can inhibit apoptotic cell death. Apoptosis was observed in the small intestine of animals on a zinc-deficient diet (Elmes 1977), and a zinc-chelator was found to induce apoptosis in human thymocytes and leukemia cells (McCabe et al. 1993). The induction of apoptosis by irradiation, anti-cancer drugs or tumor necrosis factor (TNF) was prevented by zinc (Shimizu et al. 1990, Telford et al. 1991, Zalewski et al. 1991, Leccia et al. 1993, Shiokawa et al. 1994, Tanuma \& Shiokawa 1994, Fady et al.1995). In contrast, however, a few reports have suggested that zinc actually induces apoptotic cell death (Telford \& Fraker 1995, Manev et al. 1997, Paramanantham et al. 1997). Furthermore, zinc induced necrosis in prostate carcinoma cells (Iguchi et al. 1998).

In the present study, we show that zinc induced both necrosis and apoptosis in thyroid cancer cells. After exposure to zinc, the expression of antiapoptotic proteins was increased, and that of proapoptotic proteins was decreased. Furthermore, nuclear factor- $\kappa \mathrm{B}(\mathrm{NF}-\kappa \mathrm{B})$ was activated. These changes may be a protective mechanism of thyroid cancer cells against apoptotic cell death, and may underlie the general resistance of thyroid cancer cells to apoptotic stimuli (Arscott et al. 1997).

\section{Materials and Methods}

\section{Materials}

Antibodies to Bcl-2, Bax, Bcl-xL, NFKB1, RelA, c-Rel, $\mathrm{I} \kappa \mathrm{B}$ and actin were obtained from Santa Cruz Biotechnology Inc. (Santa Cruz, CA, USA). Antibodies to $\mathrm{Bad}$ and phosphorylated $\mathrm{Bad}$ (serine 112/136) were from New England BioLabs Inc. (Beverly, MA, USA). A caspase inhibitor, Ac-DEVD-CHO (Ac-Asp-Glu-ValAsp-CHO), was purchased from Peptide Institute Inc. (Osaka, Japan). RNase A and proteinase $\mathrm{K}$ were from Nippon Gene (Osaka, Japan). T4 polynucleotide kinase and poly $(\mathrm{dI}-\mathrm{dC}) \cdot \operatorname{poly}(\mathrm{dI}-\mathrm{dC})$ were from Promega (Madison, WI, USA). Hoechst 33342 and propidium iodide (PI) were purchased from Wako Chemical Co. 


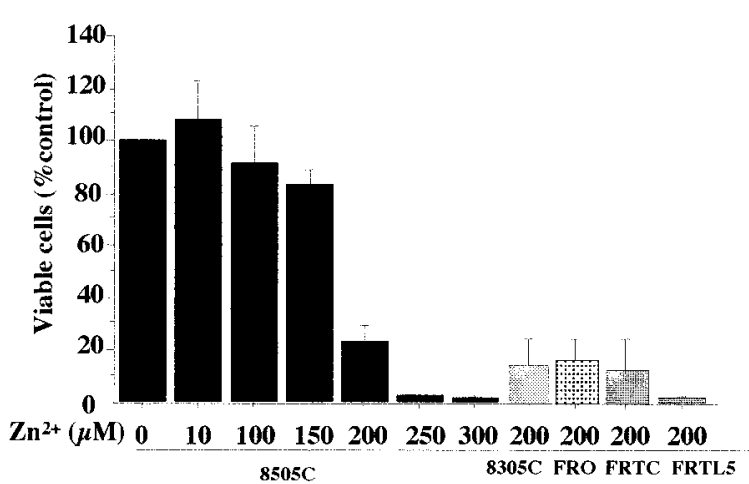

Figure $1 \mathrm{ZnCl}_{2}$-induced cell death in $8505 \mathrm{C}$ and other thyroid cancer cell lines. Means \pm S.D. from three different experiments are shown.

(Osaka, Japan). A TACS annexin V(ANV)-FITC apoptosis detection kit was from Trevigen Inc. (Gaithersburg, MD, USA).

\section{Cell culture and treatment}

The rat thyroid cancer cell line, FRTC, derived from FRTL-5, has been described previously (Iitaka et al. 1997). Cell lines 8505C (poorly differentiated human papillary thyroid carcinoma), 8305C (undifferentiated human thyroid anaplastic carcinoma) and 3T3-L1 (mouse pre-adipocytes) were obtained from the Japanese Cancer Research Resources Bank (Tokyo, Japan). FRO (human anaplastic thyroid carcinoma) (Namba et al. 1995) and MO7-E (human megakaryoblastic leukemia cells) (Avanzi et al. 1990) were obtained from Drs Namba (Nagasaki University, Japan) and Murohashi (Saitama Medical School, Japan) respectively. Human hepatocellular carcinoma cell line HepG2 (American Type Culture Collection, ATCC HB 8065) was purchased from Dainippon Pharmatheuticals (Osaka, Japan). Thyroid cells were cultured in Ham F12 medium supplemented with 10\% fetal calf serum (FCS). MC3T3-E1 (mouse osteoblastic cell line, Iitaka et al. 1994), 3T3-L1, and HepG2 cells were cultured in $\alpha$-MEM supplemented with 10\% FCS. MO7-E cells were cultured in RPMI 1640 supplemented with 10\% FCS and GM-CSF. Cells were incubated in 24-well microtiter plates (Nunc, Roskilde, Denmark) at a concentration of $1 \times 10^{4}$ cells per well, and exposed to 10-500 $\mu \mathrm{M} \mathrm{ZnCl}_{2}, \mathrm{FeSO}_{4}, \mathrm{MnCl}_{2}$, or $\mathrm{CuSO}_{4}$ for $24 \mathrm{~h}$ at $37^{\circ} \mathrm{C}$. In some experiments, cells were pretreated with $100 \mu \mathrm{M}$ Ac-DEVD-CHO for $1 \mathrm{~h}$ before adding $\mathrm{ZnCl}_{2}$. Live epithelial cells were counted by the crystal violet method (Iitaka et al. 1994), and MO7-E cells were quantified by the trypan blue exclusion method.

\section{Detection of apoptosis and necrosis}

Cells were stained with FITC-ANV (TACS annexin V-FITC apoptosis detection kit) to measure externaliz-

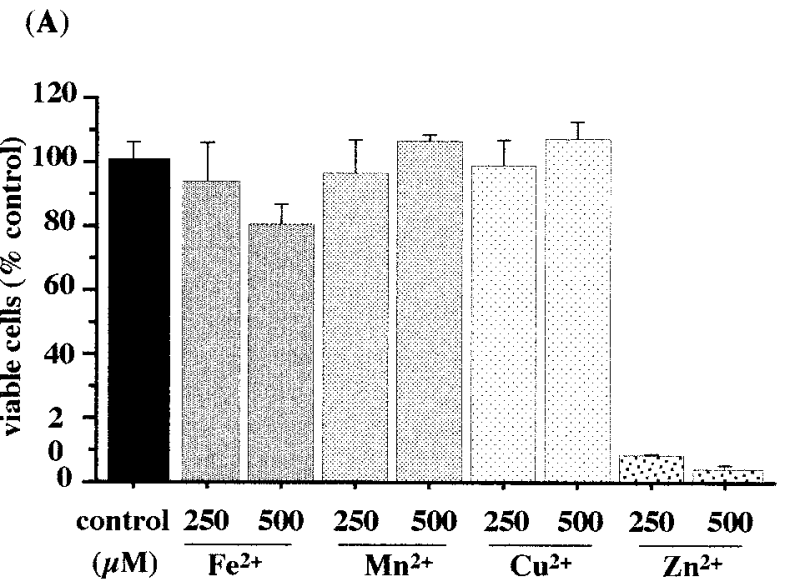

(B)

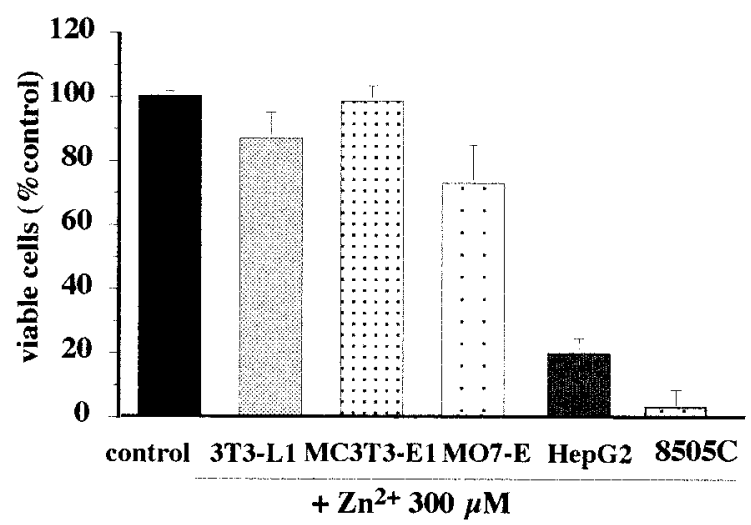

Figure 2 (A) Effect of divalent cations on 8505C thyroid cancer cells. A similar effect was observed in other thyroid cancer cell lines. (B) Effect of $300 \mu \mathrm{M}$ zinc on various cell lines. Zinc had a significant cytotoxic effect on $8505 \mathrm{C}$ and $\mathrm{HepG} 2$ cells.

Means \pm S.D. from three different experiments are shown.

ation of phosphatidyl serine, an early marker of apoptosis. Cells were also stained with Hoechst 33342 or PI after exposure to $\mathrm{Zn}^{2+}$. Hoechst 33342 stains the nuclei in both apoptotic and necrotic cells, while PI stains the nuclei in cells with damaged cell membrane (necrosis). Cells were examined under a Zeiss axioplan fluorescence microscope (Oberkochen, Germany) or analyzed by a FACScan flow cytometer (Beckton Dickinson, San Jose, CA, USA) as previously reported (van Engeland et al. 1996). DNA ladder formation was observed as described previously (Gong et al. 1994). Briefly, $1 \times 10^{6} \mathrm{Zn}^{2+}$-treated or untreated cells were collected and washed twice with cold phosphate-buffered saline (PBS). Pellets were fixed with $70 \%$ ethanol for $20 \mathrm{~h}$ at $4{ }^{\circ} \mathrm{C}$. After being washed twice 


\section{(A)}

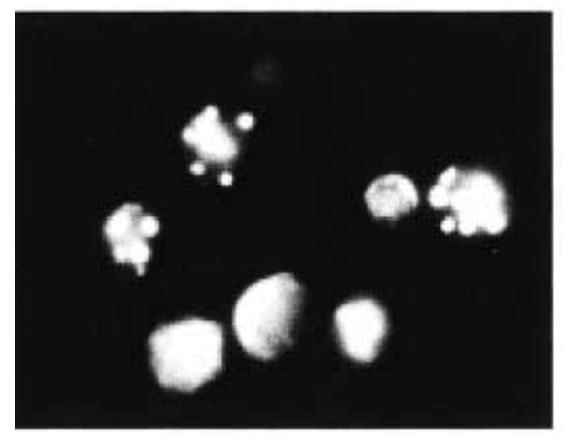

(B)

\section{Marker control zinc}

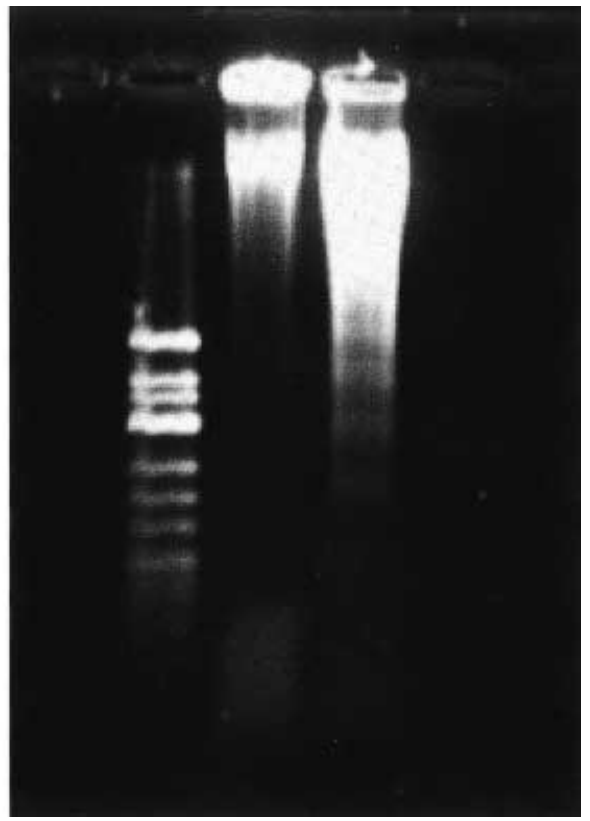

Figure 3 (A) Apoptotic bodies in $\mathrm{Zn}^{2+}$-treated $8505 \mathrm{C}$ cells stained with Hoechst 33342. The same morphological change was observed in FRTC and FRO cells following $\mathrm{Zn}^{2+}$ exposure. (B) DNA laddering was observed in $\mathrm{Zn}^{2+}$-treated $8505 \mathrm{C}$ cells.

with cold PBS, the cells were treated with $0 \cdot 2 \mathrm{M}$ phosphate-citrate buffer, $\mathrm{pH} 7 \cdot 8$, for $30 \mathrm{~min}$ at room temperature. The supernatants were recovered by centrifugation and incubated with $1 \mathrm{mg} / \mathrm{ml}$ RNase A (Nippon Gene) for $1 \mathrm{~h}$ at $37^{\circ} \mathrm{C}$, followed by proteinase $\mathrm{K}$ $\left(1 \mathrm{mg} / \mathrm{ml}\right.$; Nippon Gene) for $1 \mathrm{~h}$ at $37^{\circ} \mathrm{C}$. DNA fragments were precipitated with 2.5 vol ethanol in the presence of $0.5 \mathrm{vol} 10 \mathrm{M}$ ammonium acetate at $-20{ }^{\circ} \mathrm{C}$ for $20 \mathrm{~h}$. After centrifugation, samples were washed with $70 \%$ ethanol and resuspended in loading buffer. Electrophoresis was performed in $1 \times \mathrm{TBE}(50 \mathrm{mM}$ Tris $-\mathrm{HCl}$, pH 8.3, $50 \mathrm{mM}$ boric acid, $1 \mathrm{mM}$ EDTA) buffer on $1 \cdot 5 \%$ agarose gels containing ethidium bromide.

\section{Electrophoretic mobility shift assay (EMSA)}

To examine the activation of NF- $\kappa \mathrm{B}$, an EMSA was performed as described previously (Watanabe et al. 1997). Whole cell and nuclear extracts were prepared after lysis of the cells with NP-40 lysis buffer. An oligonucleotide containing the NF- $\mathrm{KB}$ consensus binding site (5'-AGT TGAGGGGACTTTCCCAGGC-3') was $5^{\prime}$ end-labeled using polynucleotide kinase and $\left[\gamma^{32} \mathrm{P}\right] \mathrm{ATP}$. Nuclear protein extracts $(4 \mu \mathrm{g})$ or whole cell extracts $(10 \mu \mathrm{g})$ were incubated with labeled oligonucleotide for $20 \mathrm{~min}$ at room temperature in $10 \mu \mathrm{l}$ binding mixture containing $10 \mathrm{mM}$ Tris-HCl, pH 7·5, $1 \mathrm{mM} \mathrm{MgCl}_{2}, 50 \mathrm{mM} \mathrm{NaCl}$,
$0.5 \mathrm{mM}$ EDTA, $0.5 \mathrm{mM}$ dithiothreitol, $4 \%$ glycerol, and $0.05 \mathrm{mg} / \mathrm{ml}$ poly (dI-dC) poly (dI-dC). The DNA-protein complexes were resolved by electrophoresis on $4 \%$ acrylamide gels in $1 \times \mathrm{TBE}$ at $10 \mathrm{~V} / \mathrm{cm}$ for $60 \mathrm{~min}$ at room temperature.

\section{Western blotting}

The expression of $\mathrm{Bcl}-2$, Bcl-xL, Bax, Bad, phosphorylated Bad (ser 112/136) and IKB was examined by Western blot analysis. Cell lysates were separated by SDS-PAGE on $7 \cdot 5-12 \%$ gradient polyacrylamide gels and transferred onto Hybond-ECL nitrocellulose membranes (Amersham International plc, Amersham, Bucks, UK) in $25 \mathrm{mM}$ Tris, $192 \mathrm{mM}$ glycine. Membranes were blocked in Tris-buffered saline $(20 \mathrm{mM}$ Tris- $\mathrm{HCl}, \mathrm{pH}$ $7 \cdot 5,137 \mathrm{mM} \mathrm{NaCl}$ ) containing $0 \cdot 1 \%$ Tween 20 and 3\% non-fat dry milk for $30 \mathrm{~min}$ at room temperature. The blots were incubated with antibodies to $\mathrm{Bcl}-2, \mathrm{Bcl}-\mathrm{xL}$, $\mathrm{Bax}, \mathrm{Bad}$, phospho-Bad, and IкB overnight at $4{ }^{\circ} \mathrm{C}$. The membranes were washed in Tris-buffered saline and incubated with horseradish peroxidase-conjugated goat anti-rabbit immunoglobulin G (Amersham) for $1 \mathrm{~h}$ at room temperature. The blots were visualized by the Amersham ECL system (Amersham). The expression of these proteins was quantified using NIH image software (NIH, Bethesda, MD, USA). 

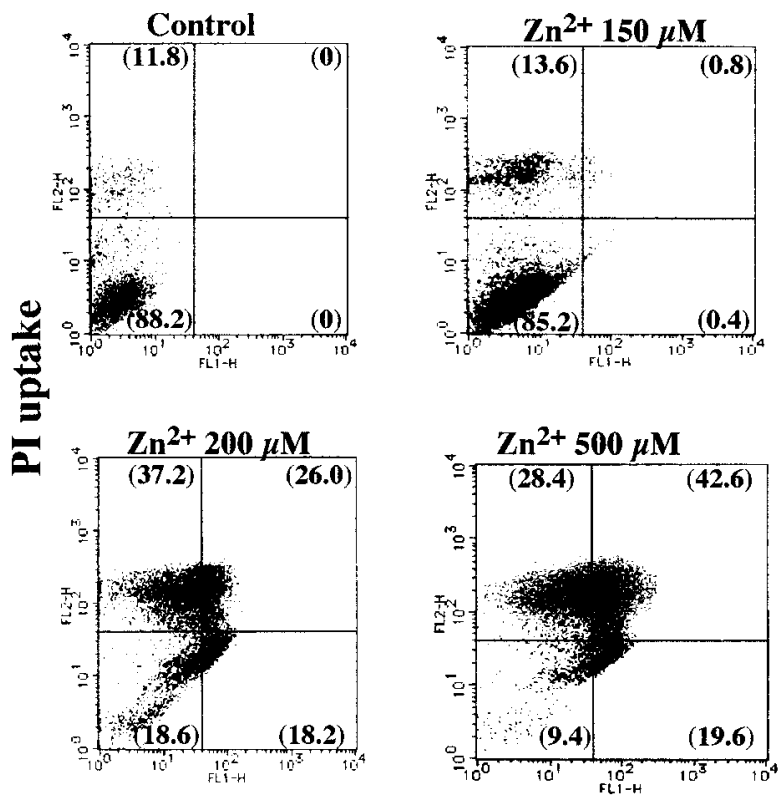

Annexin V binding

Figure 4 Flow cytometric analysis of apoptosis and necrosis in 8505C thyroid cancer cells following $\mathrm{Zn}^{2+}$ exposure. Data are representative of four separate experiments. Figures in parentheses indicate the percentage of cell numbers in each area.

Annexin $(+) / \mathrm{PI}(-)$ cells (lower right area) indicate apoptotic cells. $\mathrm{Pl}(+)$ cells (upper area) indicate necrotic cells.

\section{Statistical analysis}

The Scheffe's multiple comparison test (Figs 1 and 2) and the Student's $t$-test (Fig. 6B) were used to analyze data. A level of $P<0.05$ was accepted as statistically significant.

\section{Results}

$\mathrm{Zn}^{2+}$-induced cell death in thyroid cancer cells

As shown in Fig. $1, \mathrm{ZnCl}_{2}$ at concentrations of $150 \mu \mathrm{M}$ or higher induced prominent cell death in a number of thyroid cancer cell lines as well as in FRTL-5 cells. Other divalent cations, including $\mathrm{Cu}^{2+}, \mathrm{Fe}^{2+}$ and $\mathrm{Mn}^{2+}$ had no significant cytotoxic effect on these cells, even at concentrations as high as $500 \mu \mathrm{M}$ (Fig. 2A). Non-thyroid cell lines, including MC3T3-E1, 3T3-L1 and MO7-E, were resistant to exposure to $\mathrm{Zn}^{2+}$ concentrations up to $300 \mu \mathrm{M}$

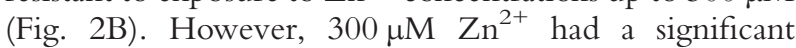
cytotoxic effect on HepG2 cells. $\mathrm{ZnCl}_{2}$ at $500 \mu \mathrm{M}$ also had a significant cytotoxic effect on MO7-E cells (number of viable cells was $54 \pm 10 \%$ of the control), but not on MC3T3-E1 and 3T3-L1 cells.

Cells with apoptotic bodies and DNA laddering were observed in $\mathrm{Zn}^{2+}$-treated thyroid cancer cells (Fig. 3). Flow cytometric analysis showed that the number of $\mathrm{PI}(+)$

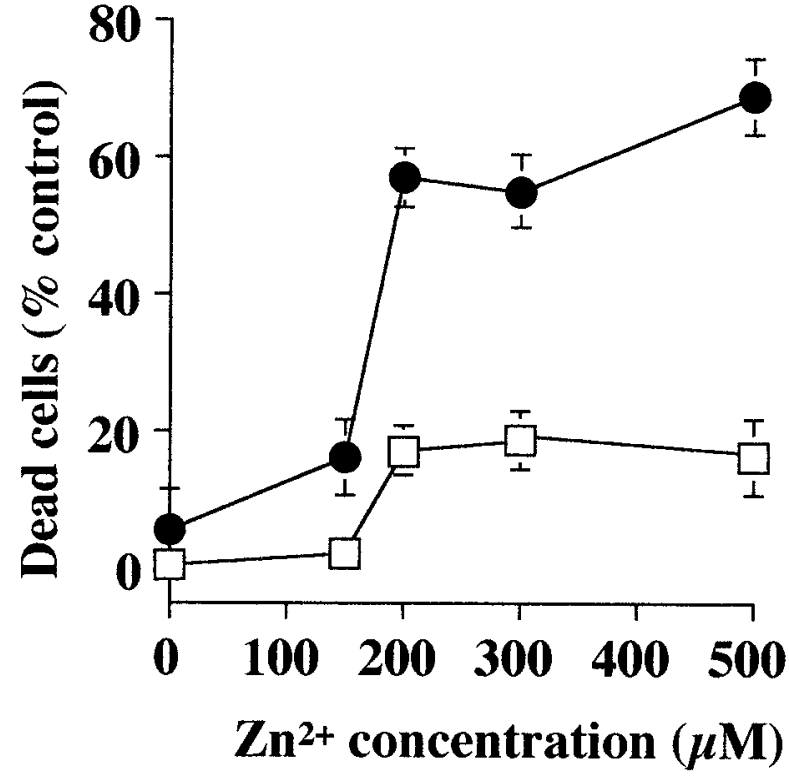

Figure 5 Effect of $\mathrm{Zn}^{2+}$ on the induction of $\mathrm{ANV}(+) / \mathrm{PI}(-)$ apoptosis $(\square)$ or $\mathrm{PI}(+)$ necrosis $(\bullet)$ in $8505 \mathrm{C}$ thyroid cancer cells. Results are means \pm S.E. from four different experiments.

necrotic cells as well as $\mathrm{ANV}(+) / \mathrm{PI}(-)$ apoptotic cells increased after exposure to $150 \mu \mathrm{M}$ or higher concentrations of zinc (Fig. 4). Necrosis was induced by zinc in a dose-dependent manner (Fig. 5). However, apoptotic cells were not further increased by $200 \mu \mathrm{M}$ or higher concentrations of zinc. As the concentration of zinc increased, the number of $\mathrm{ANV}(+) / \mathrm{PI}(+)$ cells (including secondary necrotic cells following apoptosis) also increased. As shown in Fig. 6A, cells were rapidly killed through necrosis following $300 \mu \mathrm{M}$ zinc administration. On the other hand, apoptosis as well as necrosis were gradually induced by $180 \mu \mathrm{M}$ zinc. The cytotoxic effect of $180 \mu \mathrm{M}$ zinc was significantly inhibited by the caspase inhibitor Ac-DEVD-CHO, whereas cell death induced by $300 \mu \mathrm{M}$ zinc was not inhibited (Fig. 6B).

\section{$\mathrm{Zn}^{2+}$-induced DNA binding activity of NF- $\kappa \mathrm{B}$}

The inhibitory protein $\mathrm{I} \kappa \mathrm{B}$ was degraded rapidly and increased binding of NF- $\mathrm{KB}$ in thyroid cancer cells was observed following $\mathrm{Zn}^{2+}$ exposure (Fig. 7). Supershift analysis revealed that activated $\mathrm{NF}-\kappa \mathrm{B}$ was mainly a heterodimer of NFKB1 and RelA (Fig. 7).

\section{Expression of proapoptotic and antiapoptotic proteins after $\mathrm{Zn}^{2+}$ exposure}

The expression of the proapoptotic proteins Bax and Bad was significantly decreased after exposure to $200 \mu \mathrm{M} \mathrm{Zn}{ }^{2+}$ (Fig. 8). The expression of phosphorylated Bad at serine 112 and 136, which exerts antiapoptotic effects, was 
(A)

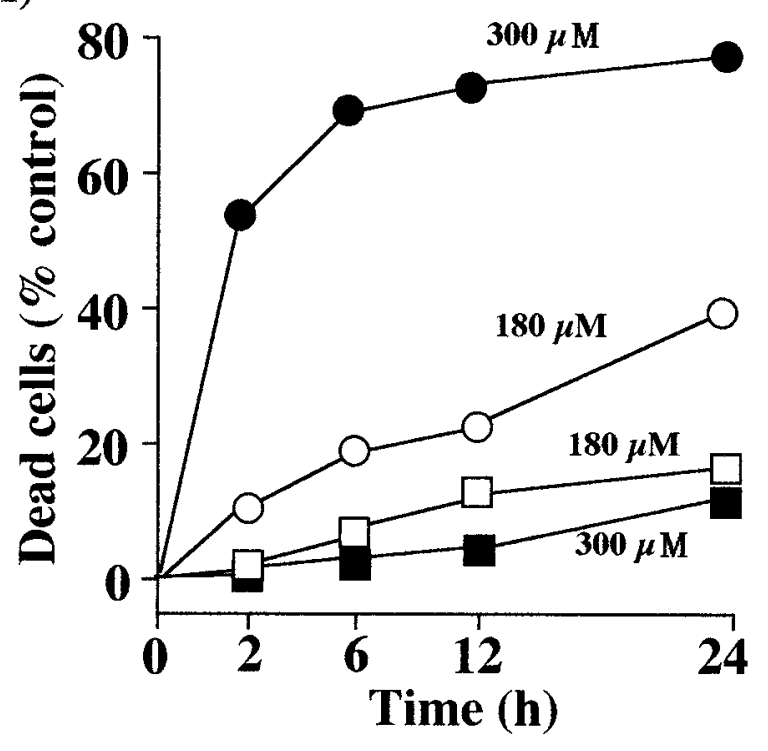

(B)

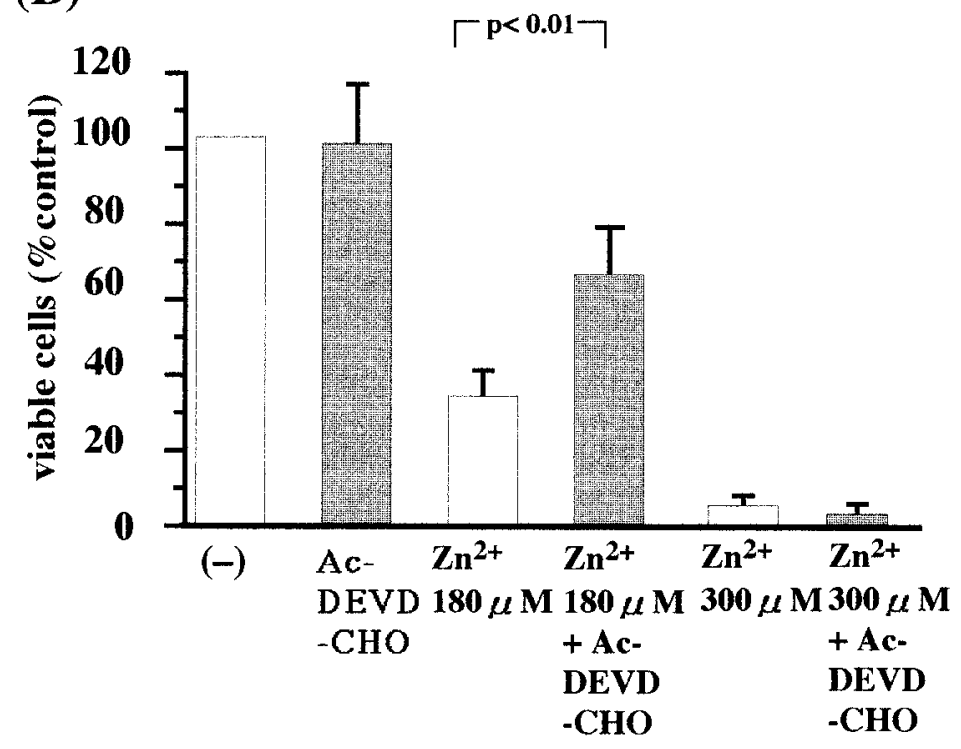

Figure 6 (A) Induction of apoptosis $(\mathrm{ANV}(+) / \mathrm{PI}(-)$, boxes) and necrosis $(\mathrm{PI}(+)$, circles) by zinc. Necrosis was rapidly induced by $300 \mu \mathrm{M}$ zinc $(\mathbf{)})$, whereas both apoptosis $(\square)$ and necrosis $(\bigcirc)$ were induced by $180 \mu \mathrm{M}$ zinc. (B) Effect of a caspase inhibitor, Ac-DEVD-CHO, on $\mathrm{Zn}^{2+}$-induced cell death. The cytotoxic effect of $180 \mu \mathrm{M}$ zinc was significantly inhibited $(P<0 \cdot 01)$, but that of $300 \mu \mathrm{M}$ zinc was not. Means \pm S.D. from three different experiments are shown.

gradually but markedly increased. A slight increase in expression of the antiapoptotic protein $\mathrm{Bcl}-2$ was observed. There was no significant change in the expression of $\mathrm{Bcl}-\mathrm{xL}$. These changes were not observed in zinc-resistant MC3T3E-1 cells even after $500 \mu \mathrm{M}$ zinc treatment (data not shown).

\section{Discussion}

This study demonstrated that $\mathrm{Zn}^{2+}$ had a potent cytotoxic effect on thyroid cancer cell lines and FRTL-5. High concentrations of $\mathrm{ZnCl}_{2}$ induced both necrosis and apoptosis. Previous reports have shown that $\mathrm{Zn}^{2+}$ prevented 


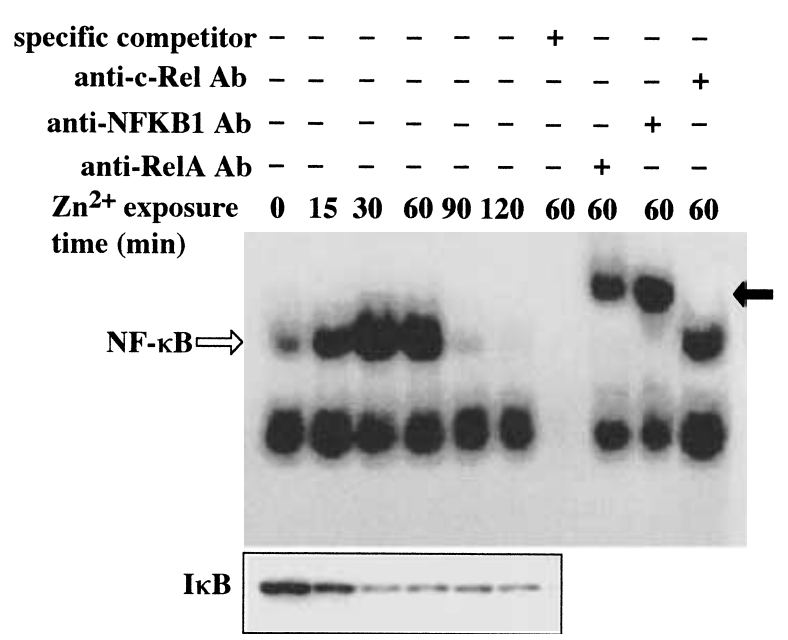

Figure $7 \mathrm{I} \mathrm{KB}$ was degraded and DNA binding of NF- $\kappa \mathrm{B}$ (open arrow) increased in $8505 \mathrm{C}$ cells after exposure to $\mathrm{Zn}^{2+}$. Activated NF- $\kappa$ B was a heterodimer of NFKB1 and RelA as demonstrated by a supershift assay (solid arrow). Similar results were obtained using FRO and FRTC cells.

apoptotic cell death in various cell types when apoptosis was induced with various cytotoxic agents including TNFa, cycloheximide, and UV and $\gamma$-irradiation (Shimizu et al. 1990, Telford et al. 1991, Zalewski et al. 1991, Leccia et al. 1993, Shiokawa et al. 1994, Tanuma \& Shiokawa 1994, Fady et al. 1995). The mechanism of the antiapoptotic effect of $\mathrm{Zn}^{2+}$ was thought to be via its inhibitory effect on DNases (Shiokawa et al. 1994, Tanuma \& Shiokawa 1994), or on poly(ADP-ribose) synthetase (Shimizu et al. 1990). Conversely, $\mathrm{Zn}^{2+}$ appeared to induce apoptotic cell death in a particular subset of mouse thymocytes, rat cerebellar granule cells and human liver cells (Telford \& Fraker 1995, Manev et al. 1997, Paramanantham et al. 1997). We also confirmed the cytotoxic effect of $\mathrm{Zn}^{2+}$ on $\mathrm{HepG} 2$ cells. Telford et al. (1991) and Telford and Fraker (1995) reported that high concentrations $(>200 \mu \mathrm{M})$ of $\mathrm{Zn}^{2+}$ inhibited glucocorticoid-induced apoptosis in mouse thymocytes, whereas lower concentrations $(80-200 \mu \mathrm{M})$ of $\mathrm{Zn}^{2+}$ were shown to induce apoptotic cell death in these cells. Provinciali et al. (1995) also reported a similar dose-dependent effect of $\mathrm{Zn}^{2+}$ on apoptosis in mouse thymocytes. In the present study, concentrations of $\mathrm{Zn}^{2+}$ at $150 \mu \mathrm{M}$ or higher were observed to induce cell death in various thyroid cancer cell lines in a dose-dependent manner.

Manev et al. $(1995,1997)$ have shown that the neurotoxicity of $\mathrm{Zn}^{2+}$ on rat cerebellar granule neurons involved both necrotic and apoptotic cell death. They suggested that calcium channel blocker-sensitive mitochondrial injury and DNA damage were involved in the protein synthesisdependent neurotoxicity of $\mathrm{Zn}^{2+}$. These authors reported that actinomycin $\mathrm{D}$ and calcium channel blockers reduced mitochondrial injury and cell death. In our study, we did not observe any inhibitory effect of actinomycin $\mathrm{D}$ or calcium channel blockers on $\mathrm{Zn}^{2+}$-induced cell death in thyroid cancer cells (data not shown). Zinc has also been reported to induce necrosis in prostate carcinoma cells (Iguchi et al. 1998).

The present study shows that necrosis was induced in a dose-dependent manner by zinc. Higher concentrations of zinc rapidly induced necrotic cell death, whereas relatively lower concentrations of zinc induced apoptosis as well as necrosis in a time-dependent fashion. This suggests that zinc can induce two cytotoxic pathways in thyroid cancer cells. It is of interest that about $65 \%$ of cell death induced by $180 \mu \mathrm{M}$ zinc could be rescued by the caspase inhibitor in spite of the fact that only $20 \%$ of cells are supposed to be killed by apoptosis. This suggests that secondary necrosis may be induced following apoptosis by relatively lower concentrations of zinc. Blom et al. (1999) reported that permeabilization of the plasma membrane (i.e. necrosis) was induced in some hepatocytes after the induction of apoptosis. Another possibility is that the caspase inhibitor actually inhibited necrosis. Warny and Kelly (1999)

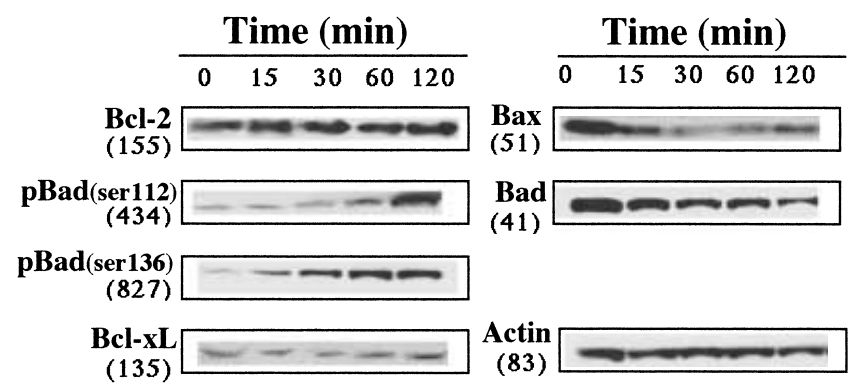

Figure 8 Expression of apoptosis-related proteins in 8505C thyroid cancer cells following exposure to $200 \mu \mathrm{M} \mathrm{Zn}^{2+}$. Figures in parentheses indicate the percentage ratio of amounts of each protein expressed before $\mathrm{Zn}^{2+}$ exposure and $120 \mathrm{~min}$ after. Data are representative of two different experiments. 
showed that caspase-like proteases were activated when necrosis was induced, and that the caspase inhibitor inhibited necrosis. In our experiments, however, the caspase inhibitor could not inhibit the cytotoxic effect of $300 \mu \mathrm{M}$ zinc. We do not know why higher concentrations of zinc still induce apoptosis in a minor population of thyroid cancer cells. Palomba et al. (1996) found that the same initial damage can be a triggering event for both apoptosis and necrosis. They concluded that necrosis does not appear to be a passive response to overwhelming damage. Although the mechanism of induction of apoptosis or necrosis by zinc still remains to be elucidated, it was reported that intracellular ATP (Eguchi et al. 1997, Leist et al. 1997) or reduced glutathione (Fernandes \& Cotter 1994) levels may serve as a switch between apoptosis and necrosis.

Exposure of thyroid cancer cells to $\mathrm{Zn}^{2+}$ led to a marked increase in expression of the antiapoptotic protein phosphorylated Bad, and a concurrent decrease in expression of the proapoptotic proteins Bax and Bad. This, in addition to a slight increase in $\mathrm{Bcl}-2$ expression, results in an increase in the ratio of antiapoptotic proteins and proapoptotic proteins. These changes were not observed in zinc-resistant cells even after exposure to high concentrations of zinc. Furthermore, $\mathrm{Zn}^{2+}$ increased the binding of NF- $\kappa B$ to DNA in thyroid cancer cells. The inhibitory protein, I $\mathrm{KB}$, was rapidly degraded following $\mathrm{Zn}^{2+}$ exposure, resulting in translocation of $\mathrm{NF}-\mathrm{\kappa B}$ into the nucleus. Activated NF- $\kappa B$ was mainly a heterodimer of NFKB1 (p50) and RelA (p65). Recent studies have provided convincing evidence that NF- $\kappa B$ is involved in the inhibition of apoptosis (Beg et al. 1995, Antwerp et al. 1996, Beg \& Baltimore 1996, Wang et al. 1996). These observations suggest that antiapoptotic pathways were activated in thyroid cancer cells following $\mathrm{Zn}^{2+}$ exposure. This may be a self-defence mechanism against external apoptotic stimuli, although necrotic cell death could not be prevented. This self-defence mechanism may be one reason why thyroid cells are resistant to apoptotic stimuli (Arscott et al. 1997).

The prognosis of anaplastic or poorly differentiated thyroid carcinomas is extremely poor because of the resistance of these cancers to chemotherapeutic agents and/or radiation. Since administration of excessive amounts of zinc compounds does not seem to result in any adverse effects (Vallee \& Falchuk 1993), the cytotoxic effect of zinc may be useful in the treatment of anaplastic and/or other thyroid cancers, especially when zinc is injected into the tumor percutaneously.

\section{Acknowledgements}

The authors would like to thank Ms T Suzuki for her excellent technical assistance. We are also grateful to Dr Namba and Dr Murohashi for providing us with cells.

\section{References}

Antwerp DJV, Martin SJ, Kafri T, Green DR \& Verma IM 1996 Suppression of TNF- $\alpha$-induced apoptosis by NF-KB. Science $\mathbf{2 7 4}$ 787-789.

Arscott PL, Knapp J, Rymaszewski M, Barton JL, Bretz JD, Thompson NW \& Baker JR Jr 1997 Fas (APO-1, CD95)-mediated apoptosis in thyroid cells is regulated by a labile protein inhibitor. Endocrinology 138 5019-5027.

Avanzi GC, Brizzi MF, Giannotti J, Ciarletta A, Yang YC, Pegoraro L \& Clark SC 1990 MO7e human leukemic factor-dependent cell line provides a rapid and sensitive bioassay for human cytokines GM-CSF and IL-3. Journal of Cellular Physiology 145 458-464.

Beg AA \& Baltimore D 1996 An essential role for NF- $\mathrm{KB}$ in preventing TNF- $\alpha$-induced cell death. Science 274 782-784.

Beg AA, Sha WC, Bronson RT, Ghosh S \& Baltimore D 1995 Embryonic lethality and liver degeneration in mice lacking the RelA component of NF-кB. Nature 376 167-170.

Blom WM, De Bont HJGM, Meijerman I, Kuppen PJK, Mulder GJ \& Nagelkerke JF 1999 Interleukin-2-activated natural killer cells can induce both apoptosis and necrosis in rat hepatocytes. Hepatology 29 785-792.

Eguchi Y, Shimizu S \& Tsujimoto Y 1997 Intracellular ATP levels determine cell death fate by apoptosis or necrosis. Cancer Research 57 1835-1840.

Elmes ME 1977 Apoptosis in the small intestine of zinc-deficient and fasted rats. Journal of Pathology 123 219-223.

van Engeland M, Ramaekers FC, Schutte B \& Reutelingsperger CP 1996 A novel assay to measure loss of plasma membrane asymmetry during apoptosis of adherent cells in culture. Cytometry 24 131-139.

Fady C, Gardner A, Jacoby F, Brinskin K, Tu Y, Schmid I \& Lichtenstein A 1995 Atypical apoptotic cell death induced in L929 targets by exposure to tumor necrosis factor. Journal of Interferon Cytokine Research 15 71-80.

Fernandes RS \& Cotter TG 1994 Apoptosis or necrosis: intracellular levels of glutathione influence the mode of cell death. Biochemical Pharmacology 48 675-681.

Gong J, Traganos F \& Darzynkiewicz Z 1994 A selective procedure for DNA extraction from apoptotic cells applicable for gel electrophoresis and flow cytometry. Annals of Biochemistry 218 314-319.

Iguchi K, Hamatake M, Ishida R, Usami Y, Adachi T, Yamamoto H, Kohsida K, Uchibayashi T \& Hirano K 1998 Induction of necrosis by zinc in prostate carcinoma cells and identification of proteins increased in association with this induction. European Journal of Biochemistry 253 766-770.

Iitaka M, Kitahama S \& Ishii J 1994 Involvement of protein kinase A and $\mathrm{C}$ in the production of interleukin-1a-induced prostaglandin $\mathrm{E}_{2}$ from mouse osteoblast-like cell line, MC3T3-E1. Biochimica et Biophysica Acta 1221 78-82.

Iitaka M, Fukasawa N, Kitahama S, Miura S, Kawakami Y, Sato H, Sugano S, Ishii J \& Katayama S 1997 Transplantable rat thyroid cancer cell line FRTC transformed with muramyl dipeptide. British Journal of Cancer 75 40-46.

Leccia MT, Richard MJ, Beani JC, Faure H, Monjo AM, Cadet J, Amblard P \& Favier A 1993 Protective effect of selenium and zinc on UV-A damage in human skin fibroblasts. Photochemistry and Photobiology 58 548-553.

Leist M, Single B, Castoldi AF, Kühnle S \& Nicotera P 1997 Intracellular adenosine triphosphate (ATP) concentration: a switch in the decision between apoptosis and necrosis. Journal of Experimental Medicine 185 1481-1486.

McCabe MJ Jr, Jiang SA \& Orrenius S 1993 Chelation of intracellular zinc triggers apoptosis in mature thymocytes. Laboratory Investigation 69 101-110. 
Manev H, Cagnoli CM, Atabay C, Kharlamov E, Ikonomovic MD \& Grayson DR 1995 Neuronal apoptosis in an in vitro model of photochemically induced oxidative stress. Experimental Neurology 133 198-206.

Manev H, Kharlamov E, Uz T, Mason RP \& Cagnoli CM 1997 Characterization of zinc-induced neuronal death in primary cultures of rat cerebellar granule cells. Experimental Neurology 146 171-178.

Namba H, Hara T, Tsukazaki T, Migita K, Ishikawa N, Ito K \& Nagataki S 1995 Radiation-induced $\mathrm{G}_{1}$ arrest is selectively mediated by the p53-WAF1/Cip1 pathway in human thyroid cells. Cancer Research 55 2075-2080.

Palomba L, Sestili P, Cattabeni F, Azzi A \& Cantoni O 1996 Prevention of necrosis and activation of apoptosis in oxidatively injured human myeloid leukemia U937 cells. FEBS Letters 390 91-94.

Paramanantham R, Sit K-H \& Bay B-H 1997 Adding Zn ${ }^{2+}$-induced DNA fragmentation and cell condensation in cultured human Chang liver cells. Biological Trace Element Research 58 135-147.

Provinciali M, Di Stefano G \& Fabris N 1995 Dose-dependent opposite effect of zinc on apoptosis in mouse thymocytes. International Journal of Immunopharmacology 17 735-744.

Raff MC 1992 Social controls on cell survival and cell death. Nature 356 397-400.

Shimizu T, Kubota M, Tanizawa A, Sano H, Kasai Y, Hashimoto H, Akiyama Y \& Mikawa H 1990 Inhibition of both etoposide-induced DNA fragmentation and activation of poly(ADP-ribose) synthesis by zinc ion. Biochemical and Biophysical Research Communications 169 $1172-1177$.

Shiokawa D, Ohyama H, Yamada T, Takahashi K \& Tanuma S 1994 Identification of an endonuclease responsible for apoptosis in rat thymocytes. European Journal of Biochemistry 226 23-30.
Tanuma S \& Shiokawa D 1994 Multiple forms of nuclear deoxyribonuclease in rat thymocytes. Biochemical and Biophysical Research Communications 203 789-797.

Telford WG \& Fraker PJ 1995 Preferential induction of apoptosis in mouse $\mathrm{CD}^{4+} \mathrm{CD}^{8+}$ abTCR ${ }^{10} \mathrm{CD} 3 \mathrm{e}^{\text {lo }}$ thymocytes by zinc. Journal of Cellular Physiology 164 259-270.

Telford WG, King LE \& Fraker PJ 1991 Evaluation of glucocorticoidinduced DNA fragmentation in mouse thymocytes by flow cytometry. Cell Proliferation 24 447-459.

Vallee BL \& Falchuk KH 1993 The biochemical basis of zinc physiology. Physiological Reviews 73 79-118.

Wang C-Y, Mayo MW \& Baldwin AS 1996 TNF- and cancer therapy-induced apoptosis: potentiation by inhibition of NF- $\mathrm{KB}$. Science 274 784-787.

Warny M \& Kelly C 1999 Monocytic cell necrosis is mediated by potassium depletion and caspase-like proteases. American Journal of Physiology 276 C717-C724.

Watanabe N, Iwamura T, Shinoda T \& Fujita T 1997 Regulation of NFKB1 proteins by the candidate oncoprotein BCL-3: generation of NF- $\mathrm{KB}$ homodimers from the cytoplasmic pool of p50-p105 and nuclear translocation. EMBO Journal 16 3609-3620.

Williams GT \& Smith CA 1993 Molecular regulation of apoptosis: genetic controls on cell death. Cell 74 777-779.

Zalewski PD, Forbes IJ \& Giannakis C 1991 Physiological role for zinc in prevention of apoptosis (gene-directed death). Biochemical and Biophysical Research Communications 24 1093-1101.

Received in final form 2 January 2001

Accepted 9 January 2001 